\title{
East and West, Ancient and Modern: A Book Review About CAO Shun-qing's A History of Chinese and Foreign Literary Theories
}

\author{
WANG Miao-miao \\ North China Electric Power University, Beijing, China
}

\begin{abstract}
A History of Chinese and Foreign Literary Theories (2012) edited by Professor CAO Shun-qing is the first monograph of literary theory history that crosses the Eastern and Western cultural circles and integrates the world's literary theories into one from the perspective of General Literature. It is the only historical work that widely covers Chinese literary theories. It shows a general development of Chinese and foreign literary theories to readers from the perspective of General Literature. It presents the different characteristics of literary theories of different countries and their unique contributions to the world literary theories. It is featured by comparisons between ancient and today's literary theories, between Chinese and foreign literary theories, and between literary theories of different cultures. This book shows a general development of Chinese and foreign literary theories to readers from the perspective of General Literature. It presents the different characteristics of literary theories of different countries and their unique contributions to the world literary theories. It discloses the basic rules of literary theories of various nations in the world and contributes to setting up the "General Literary Theory".

Keywords: General Literary Theory, Chinese and Foreign Literary Theories, development of literary history, cross-heterogeneous culture, commensurability
\end{abstract}

\section{Introduction}

Up to now, there has not born a monograph of literary theory history (or literary criticism history or literary thoughts history) in Chinese that crosses the Eastern and Western cultural circles and integrates the world's literary theories into one from the perspective of General Literature. Existing monographs on the history of literary theoretical criticism and the history of Western literary criticism are either limited to a single country (e.g., the history of Chinese literary criticism, the history of Sanskrit poetics, and the history of Japanese literary criticism), or confined to criticisms about the literary theories of a same cultural circle (e.g., A Short History of Literary Criticism (1957) by William K. Wimsatt and Cleanth Brooks, A History of Modern Criticism (1986) by Rene Wellek, A History of Chinese and Japanese Literary Criticism (1987), and A History of Chinese and Korean Literary Criticism (2003)). And current literary theories neither favor the mutual exchanges and understandings of the world's literary thoughts, nor serve to a deep understanding of ethnic characteristics and theories of different countries and cultural circles, or the establishment of the General Literary Theory. Therefore, a book which could embrace a global literature history from the international

WANG Miao-miao, lecturer, Ph.D. candidate, School of Foreign Languages, North China Electric Power University. 
perspective of view is particularly important. A History of Chinese and Foreign Literary Theories (2012) edited by Professor CAO Shun-qing and others is the only historical work that widely covers Chinese literary theories and foreign literary theories. This book exhibits the development of Chinese and foreign literary theories to readers from the angle of General Literature, and reveals the basic rules of literary theories of various nations and contributes to establish the "General Literary Theory".

There are four volumes and eight parts in A History of Chinese and Foreign Literary Theories, with 4,200 pages in all from the preface, the text to the postscript. It is the only historical work that widely covers Chinese and foreign literary theories in the world. Part 1 in the first volume discusses the development of the literary criticism history from the longitudinal perspective and makes comparisons from the horizontal perspective. Part 2 expounds the Chinese and foreign literary theories before the 2nd century BC. It uses chronology to record events and divides the Chinese and foreign literary theory history into different phases based on the similar development stages of various cultural circles. The history before the 2 nd century $\mathrm{BC}$ is the first phase. The second volume includes Part 3 (literary theories from the end of the 3rd century BC to the 2nd century AD) and Part 4 (literary theories from the 3rd century AD to the 6th century AD), with the span of about 900 years. The third volume includes Part 5 (literary theories from the 7th century AD to the 9th century AD) and Part 6 (literary theories from the 10th century AD to the 13th century AD), with the span of about 600 years. High and Late Middle Ages Specifically, this time period is equivalent to the High and Late Middle Ages in Europe, or from Sui Dynasty, Tang Dynasty, the Five Dynasties to North and South Song Dynasty (581-1279). The fourth volume includes Part 7 (literary theories from the 14th century AD to the 16th century AD) and Part 8 (literary theories from the 17th century AD to the 19th century AD), with the span of 500 years. It covers China, Greek, India, Rome, Egypt, Arabia, Persia, Italy, Britain, France, Germany, Japan, Korea, Vietnam, Thailand, and the United States, of different civilizations in four continents. Its comprehensiveness is beyond doubt. This book mentions in general or details most Chinese and foreign monographs of literary theories, including books of Indian literary theory of Natyasastra, Kavyalankar, Kavyadarsa, and Dhvanyaloka rooted in Ganges River Basin, and Chinese literary theories of Mao Shi Xu (《毛诗序》), The Literary Mind and the Carving Dragons (《文心雕龙》), Poetic Character (《诗品》), and The Origin of Poetry (《原诗》), etc.. Even so, it fails to cover every aspect of the Indian and Chinese literary theories, not to mention that of the whole world. Hence, it is only "relatively" comprehensive. This book picks up key points of Chinese and foreign literary theories for further illustration. The Poetics by Aristotle, Chinese Chuang Tzu, The Literary Mind and the Carving Dragons, Natyasastra of India, Aesthetics by Hegel are recorded of great length. At least 41 pages (pp. 581-621) talk about the tragic theory and aesthetic effect of The Poetics, 81 pages (pp. 622-702) discuss on Chuang Tzu, 93 pages (pp. 948-1040) for Natyasastra and 44 pages (pp. 3534-3577) for Aesthetics, not to mention the 183 pages (pp. 1638-1820) for LIU Xie's The Literary Mind and the Carving Dragons in Chapter 6 of Part 4, the length of which can equal to a monograph.

\section{True Meaning of Ancient Literary Theories of the World}

A History of Chinese and Foreign Literary Theories does not call itself a history for no reasons. It aims to restore the true meaning of ancient literary theories of the world (before the 19th century) from the perspective of General Literature, focusing on the exploration and summary of the discourses of Chinese literary theories. In Chapter 1 of Volume I, The Literary Mind and the Carving Dragons: Historical Writings, it says: "Books of history must absorb the learning of hundreds of authors, stand the test of thousands of years, show evidence of 
the rise and fall of dynasties, and serve as a mirror of prosperity or decline" (Shih, trans. p. 34). In a word, it means that the rise and fall of countries should be recorded in the timeline of history. This rule applies to the history of literary theories, which Professor CAO achieves in his works. In terms of rise and fall, this book defines the "foundation period", "peak period", and "splendid period" in the history of Chinese and foreign literary theories. Plato and Aristotle of Greek, Confucius and Chuang Tzu of the ancient China have all laid a solid foundation for the Chinese and Western literary theories. The Literary Mind and the Carving Dragons and Poetic Character, produced in the Northern and Southern Dynasties of China, represent "the most splendid period in China and another peak of the world's ancient literary theories". Indian "literary theories rose in the 7th century AD and moved up to its heyday thereafter". "The 17th century to the 19th century was the period when Western literary theories went to its peak and when it blossomed in radiant splendor". ${ }^{3}$

A History of Chinese and Foreign Literary Theories is featured by comparisons between ancient and today's literary theories, between Chinese and foreign literary theories, and between literary theories of different cultures. This book pays great attention to the comparative study crossing different cultures from the perspective of tracing the cultural origins. This is evidenced by many titles of the chapters and sections, such as "Longitudinal Comparison of Chinese and Foreign Cultures and Literary Theories", "Comparison of the Theories of Harmony in Early China and Western Countries", "Comparison Between Taoism and Logos", 6 "Comparison Between Mao Shi Xu and The Poetics by Aristotle", "Comparison Between Art Poetic and Yue Ji", 8 "Comparison Between The Poetics and Natyasastra", "Comparison Between Chinese Han Dynasty and Ancient Rome on Ancients and Moderns", "Comparison Between Poetic Characteristics and Arabian "Grade Theory"," "Comparison Among the Vakrokti Theory of India, Chinese and Western Literary Theories", ${ }^{12}$ "Comparison Among Persian, Arabian and Chinese Literary Theories", ${ }^{13}$ and "Comparison Between Chinese and Western Narrative Theories", ${ }^{14}$ etc.. Titles with "comparison" are as many as 30. Even if there is no "comparison" in the titles, some passages in many chapter and sections also follow the way of comparison. This suggests that the book is equipped with a broad horizon, a comparative thinking and a comprehensive perspective. These are where the value of the book lies in. Through the trans-cultural researches, this book is trying to find out a feasible approach to the operating mechanism and rules of oriental and Western cultures. We could not only make a comparison among different cultural spirits of heterogeneous cultural circles but also summarize the growth and operating rules of all cultures. This is significant in that it deepens our understanding

\footnotetext{
1 “中国文学理论辉煌灿烂的时代, 也是整个世界古代文论的又一高峰。” (CAO, 2012, pp. 100-101)

2 “文学理论于公元 7 世纪开始崛起, 走向辉煌之巅。” (CAO, 2012, p. 102)

3 “17- 19世纪是西方文化走向高峰, 西方文论异彩纷呈的辉煌时代。” (CAO, 2012, p. 146)

4 “中外文化与文论的纵向比较” (CAO, 2012, p. 175).

5 “中西早期和谐论比较” (CAO, 2012, p. 276).

6 “道与罗格斯之比较” (CAO, 2012, p. 307).

7 “《毛诗序》与亚里士多德《诗学》比较” (CAO, 2012, p. 863).

8 “《诗艺》与《乐记》的比较” (CAO, 2012, p. 934).

9 “《诗学》与《舞论》的戏剧理论比较” (CAO, 2012, p. 1004).

10 “中国汉代与古罗马古今之争的比较” (CAO, 2012, p. 1186).

11 “《诗品》与阿拉伯“品级论” 的比较” (CAO, 2012, p. 1857).

12 “(印度)曲语论与中国、西方文论比较” (CAO, 2012, p. 2557).

13 “波斯与阿拉伯及中国文论的比较” (CAO, 2012, p. 2680).

14 “中国与西方叙事理论比较” (CAO, 2012, p. 3894).
} 
about the characteristics of oriental and Western literary theories and sets a lively cultural operating mechanism and rules for today's literary theory building.

\section{The Origin of Korean Literature}

For the Asian literary theories, this book gives a detailed introduction to the origin of Korean literature in 10th-13th century AD. It specifies that Korean literature consists of oral literature, literature of Han, and literature in Korea. And Korean literary history is the history of their integration and supplementation. This part also expounds the rise of Korean literature with examples of Po Xian Anthology (《破闲集》) by LI Ren-lao, Tales of White Clouds (《白云小说》) by LI Kui-bao, and Bu Xian Anthology (《补闲集》) by CUI Zi. Po Xian Anthology is a poetry created by LI Ren-lao in his late years and it is the first poetry in Korea, which summarizes poems written by his predecessors in Korea from the poetical and theoretical perspectives. LI Ren-lao sang high praise for HUANG Ting-jian's poems. As he said, "after reading HUANG Ting-jian and SU Shi's poems at Du Men, both my words and rhythm are improved, so I'm able to compose three poems". ${ }^{15}$ After Po Xian Anthology, Tales of White Clouds, and Bu Xian Anthology, there appeared Sayings of Old Man Li and The Maidservant (《栎翁婢说》) and others. Remarks on Poetry (《诗化丛林》) is the earliest anthology of poetry remarks in Korea, which was collected and compiled in 1652 by HONG Wan-zong. Until then, Korean poetics had entered into the era of a summary. Due to various geographical and historical reasons, cultural and literary exchanges had existed between China and Korea for a long time. And the literary exchanges between the two countries had a wide coverage, including circulation of literary classics, research and propagation of literary theories, spreading of art, and the introducing of the imperial examination system etc., which played great roles in promoting the development of the two countries' literary relationship. In the course of the development of Korean literature and culture, the influence of Chinese Korean culture and Korean literature is obvious to be seen. The prevalence and development of Korean Literary Review, in particular, are inseparable with Chinese ancient literary review. Korean literature started with oral literature with folk and witch song as its main literary form. The written Korean literature only thrived and obtained a quick development after being influenced by Chinese literature. With the appearance of Korean language, literature of Korea got a further development. Korean literary review has evolved along with the development of Chinese Korean literature. Korean literature theoretical system with distinctive Korean characteristics was established through the integration and exchange between Korean literature and Chinese literature.

Both of the development of Korean literature ranging from its origin to its maturity and its scope of content are closely linked with Chinese literature. The history of the two nations has been always characterized by the penetration and communication between Korean literature and Chinese literature, hence an inseparable relation between them. Korean literature has experienced several stages, including emulation of Chinese literature, adaptation of Chinese literature and its independent development. As a result, while sharing the same root with Chinese literature, Korean literature theoretical system has its own distinctive features, becoming an indispensable branch of the world literature.

\section{Longitudinal and Horizontal Literature}

Literature develops both longitudinally and horizontally. It develops longitudinally to make the national

15 “杜门黄苏两集, 然后语遒然韵锃然, 得作诗三昧。”(LI, 2003, p. 277) 
literatures passed down from generation to generation. It develops horizontally to make the literatures among all nationalities affect, collide with and converge with each other. Existing monographs of literary theories only discuss the longitudinal development while overlook the horizontal exchanges and communications. As a result, readers are unable to make a comparison and reference and lack of the deep understanding about the value and features of the world's literary theories. A History of Chinese and Foreign Literary Theories is advanced because it involves in the horizontal development. It frees us to probe the common and similar perspectives of Chinese and foreign literary theories. For example, Plato's driving poets out of the Utopia and Mo Tzu’s “Non-entertainment” (“非乐”) (p. 112); discussions about Chinese “Taoism” (“道”) and Indian "Literature” (“文”): For China, it is “Taoism” (“道”) $\rightarrow$ “The Saint” (“圣”) $\rightarrow$ “Literature” (The Five Classics) (“文” (五经)) $\rightarrow$ All literatures, while for India, it is "Sansk" $\rightarrow$ "Veda" $\rightarrow$ All literatures (p. 28); Chinese Taoism has some similarities with Greek Logos in their implication complexity and offers much to compare (p. 9, from p. 302); and Poetic Characteristics by the Chinese ZHONG Rong divides poets into different grades and so is Grade Poetry by Arabia Ibn Saradam. Interestingly, these two books both comment on around 120 poets (p. 113, pp. 1857-1875), etc.. In A History of Chinese and Foreign Literary Theories, there are some conclusions achieved from comparisons, like, "grand narrative" is transformed into "grand discourse". CAO Shun-qing comments that,

The ideas of literary criticisms of three cultural circles, namely China, India and Europe, were born almost at the same period between the 7th century AD and the 6th century AD. Particularly, the literary theoretical categories of "harmony", "taste", "emotion", "beauty" and "literature" were present in the philosophical classics, which are the origins of the world's literary criticism. ${ }^{16}$

Those who have explored the Chinese, Indian, and European cultures of the two centuries would agree with CAO. Another example of “grand discourse” is about the “rebellious wave of thought” (“反叛思想浪潮”) during the Renaissance. CAO discusses it together with the anti "rebellious wave of thought" by LI Zhi and TANG Xian-zu of the Ming Dynasty as well as that in "Bhakti Movement" of India. He says, this is "another synchronized cultural phenomenon following the Pre-Qin and Ancient Greek period". ${ }^{17}$ This conclusion is worthy of attention because it may be formed after CAO's unique observation. This book also introduces us with new theories in the 20th century that "everything has an origin" (“其来有自”) and "there is no new things under the sun” (“太阳之下无新事”). The American New Criticism has led the literature circle for decades and its influence still exists. They pay attention to the structure and "learning the present from the past” (“鉴古知 今”). People living in ancient times such as Aristotle and LI Yu also promoted the same (CAO, 2012, p. 167). The New Criticism school believes that critics have the privilege to explain the theme of a literature work from individual views, rather than only from the author's intentions. Otherwise, they would commit the intentional fallacy. CAO Shun-qing (2012) tells us that the Italian critic Francesco de Sanctis of the 19th century pointed out in On Dantes, "in all work of art, the intentional world and the real world, or to say the author's hopes and practices are distinguished from each other" (p. 160). The Mirror and the Lamp written by American literary theorist M. H. Abrams won the reputation for the classic of the literary theories of the 20th century, and his

16 “中、印、欧三大文化圈的文学批评观念几乎是同时萌芽的。大约在公元前 7一前 6 世纪, 中、印、欧各种文化典籍 中, 尤其是哲学著作中已开始出现“和”、“味”、“情”、“美”、“文”等等文学理论范畴, 这些便是世界文学批 评的滥解。” (CAO, 2012, p. 4)

17 “世界文化史上继先秦、古希腊之后的又一次意味深长的文化同步现象” (CAO, 2012, p. 138). 
"Mirror Theory" is known to all students of the department of literature. CAO Shun-qing also points out that the great Italian artist Leonardo da Vinci said that "the heart of the painter should like a mirror... to reflect things". However, Abrams thought that the "Mirror Theory" was derived from Plato (CAO, 2012, p. 131).

Besides the comparative thinking and the comprehensive perspective from the editor, we can also use rational association to witness the phenomena of "everything has an origin" and "there is no new things under the sun" of the 20th century's literary theories for ourselves. This book introduces the concept of "Vakrokti" in Kavyalankara of India of the 7th century (CAO, 2012, pp. 108-109). Based on this, we could also add that “Vakrokti Theory”, SU Shi’s “ups and downs in literature” (“文如看山不喜平”), “conceit” in British poems, "the Theory of Defamiliarization" (some called it "organized violence against language") of Russia of the 20th century are actually meaning the same. The so-called new thinking, in fact is just an old theory. In A History of Chinese and Foreign Literary Theories, there is a great length for Hegel's aesthetic theory, including the theory of "Beauty is the sensuous appearance or show of the Idea" (CAO, 2012, p. 157); T. S. Eliot of the 20th century proposed the theory of "objective correlative" and the New Criticism school pays much attention to literature's sensibility and figurativeness. YAN Yuan-shu, a famous Taiwan literary theorist died in 2012 once commented that “literature is the comic philosophy” (“文学是哲学的喜剧化”) and his idea is in alliance with Hegel's idea. YAN's another idea is that literature is the comment of the life, and he said this was inherited from Matthew Arnold's belief of the 19th century. A History of Chinese and Foreign Literary Theories cites Matthew Arnold's belief in the discussion of Arnold (CAO, 2012, p. 158, pp. 3701-3706). Natyasastra of India discusses the plot of drama and divides human behaviors into five phases. This reminds us of the basic narrative mode of Structuralism of the 20th century. Characters have three categories in Natyasastra, similar to the archetypal criticism of the 20th century, in which there are five classes of characters from myth characters to irony characters in western narratives. Homi Bhabha and Gayatri Chakravorty Spivak are famous literary theorists with Indian origins, but we are not sure whether they are familiar with the cultural heritage of India.

This book cites many examples to illustrate the commonality and commensurability between Chinese and foreign literary theories. When the author concludes the “common artistic nature and rules” (“共同的艺术本质 规律”) between the oriental and the western literary theories, he points out that employing the figurative language to show the rich content, which refers to "there's an end to the words, but not to their message" (“言 有尽而意无穷”) is one of these. The author spares no effort in writing works with implied meanings. He also lists European and American sayings in addition to Chinese ones. Indian and Japanese literary theories also share the feature of meaning beyond words. We can have a further understanding about its popularity and the broad horizon of the author. Chinese and foreign literary theories have much in common and their artistic natures share some common rules as well. This gives testimony to QIAN Zhong-shu's idea that "East, West, the spirit is the same” “( 东海西海，心理做同”). This book also points out the differences between Chinese and foreign literary theories (in recent years, he initiates the researches on variation of comparative literature), such as character and writing style are probably Chinese and foreign literary theories, and the special concepts in comparative poetics, just like qigong, are full of oriental mystery.

\section{The Aphasia of Chinese Literary Theories}

Chinese literary scholars of the 20th century applied mainly modern Western literary theories to their studies instead of Chinese literary theories, probably because they believe the latter is useless. Among all the famous and influential literary theorists of the 20th century, no Chinese are on the list, which is criticized by 
CAO Shun-qing as suffering "aphasia" (“失语症”) of Chinese literary theories. It seems unreasonable to see that such a country with thousands of years of history and the famous literary theory of The Literary Mind and the Carving Dragons became "aphasic" (“失语”) in the world literary theory circles in the 20th and 21st centuries. A History of Chinese and Foreign Literary Theories includes all kinds of theories from both micro and macro perspectives, and is written longitudinally and horizontally. Longitudinal refers to the "longitudinal development", i.e., the chronological development of theories, while horizontal means the "horizontal comparison" between different countries and cultures. In the "Preface" to this book, CAO Shun-qing emphasizes "comparison" as one of the features of this book. He points out that the comparison between Chinese and Western literary theories and their mutual explanation can

...provide a channel for dialogues between Chinese and western literary theories, and provides references for organizing discourse rules of Chinese and western literary theories, especially summarize the characteristics and rules of Chinese literary theory discourse through their comparison so as to find basal paths and methods for discourse reconstruction in Chinese literary arena. ${ }^{18}$

"Scholars of younger age" (“后学”) who admire Western and new theories should look back at traditions - not only Chinese traditions but also western ones - seriously. Only by this can we avoid being partial and "change" after "thorough understanding", which is mentioned by LIU Xie (the author of The Literary Mind and the Carving Dragons) as "making wise changes"; and only by doing so, as T. S. Eliot said, can we innovate with individual talents after learning and absorbing traditions. It can also be regarded as an innovation to collect all wisdoms in Chinese and Western literary theories and create a new literary theory system that is suitable for ancient and modern, Chinese and Western literary theory systems. The book The Literary Mind and the Carving Dragons, which contains a complete literary theory system and discusses a wide range of literary forms, is highly praised by editors of this book and many Chinese scholars on literary theories. As an eastern classic that The Poetics cannot match in many aspects, the book can serve as the basis of constructing the modern Chinese literary theory discourse and literary theory system integration or innovation. We can make our voice heard in the world literary theory circle because of such "wise changes". The author's proposition that has been put forward for so many years to turn "Carving a Dragon" into "Flying a Dragon" is based on such ideas. Apart from presenting and discussing Chinese and Western literary theories, editors of this book have analyzed The Literary Mind and the Carving Dragons in great details and compared it with several Western literary theory classics to demonstrate its special contributions, which can probably be regarded as the first call of Chinese literary theories.

\section{Conclusion}

A History of Chinese and Foreign Literary Theories is the pioneer in Chinese and Western literary theory circles. Only academic masters like Professor CAO Shun-qing, who is erudite and well versed in both Chinese and Western cultures, and ancient and modern cultures, can compose such a book. He spent about 20 years to finish the book. He really deserves the name of Changjiang Scholar Awarding Program by the Ministry of Education of China, which requires his perseverance and courage that are as great as the Yangtze River. The book discusses theories from both micro and macro perspectives, and make comparisons longitudinally and

18 “为中外文论对话提供一条通道, 为清理中外论话语规律提供若干参照, 尤其是通过中外文论话语的比较, 总结中国 文论话语特点与规律, 以寻求重建中国文论话语的基本路径及其方法” (CAO, 2012, p. 16). 
horizontally. It makes tremendous contributions to the international literary theory circles with its rich content and brilliant analysis, which makes significant contributions to the Academia of International Literary Theory.

\section{References}

Andras, C. M. (Ed.). (2010). New directions in travel writing and travel studies. Aachen: Shaker Press.

Botten, M. (2011). Herakleitos: Logos made manifest. Peterborough: FastPrint.

CAO, S. Q. (1995). 比较文学中国学派基本理论及其方法论体系初探 (Chinese school of comparative literature: The essential feature of its theory and a tentative study of its methodology). Comparative Literature in China, 1, 18-40.

CAO, S. Q. (1997). 道与逻各斯：中西文化与文论分道扬镳的起点 (Tao and Logos: Origin of division in the culture and literary theory between the East and West). Literature \& Art Studies, 6, 51-60.

CAO, S. Q. (Ed.). (2012). 中外文论史 (A history of Chinese and foreign literary theories). Chengdu: Sichuan University Press.

Hofstadter, A., \& Kuhns, R. (1976). Philosophies of art and beauty: Selected readings in aesthetics from Plato to Heidegger. Chicago: University of Chicago Press.

JIN, L. N. (Ed.). (2004). 论语译注 (Analects of Confucius). Shanghai: Shanghai Gu Ji Press.

LI, Y. (2003). 中韩文学关系史论 (A history of Chinese and Korean literary criticism). Beijing: Social Sciences Academic Press.

LIU, X. (1959). 文心雕龙 (The literary mind and the carving dragons) (V. Y. Shih, Trans.). New York: Columbia University Press.

Waley, A. (2011). Three ways of thought in ancient China. London: Routledge.

Waley, A. (Ann. \& Trans.). (1938). Analects of Confucius. London: Allen and Unwin.

ZHANG, M. T. (Ed.). (1987). 佛教与中国文化 (Buddhism and Chinese culture). Shanghai: Shanghai Bookshop Press. 